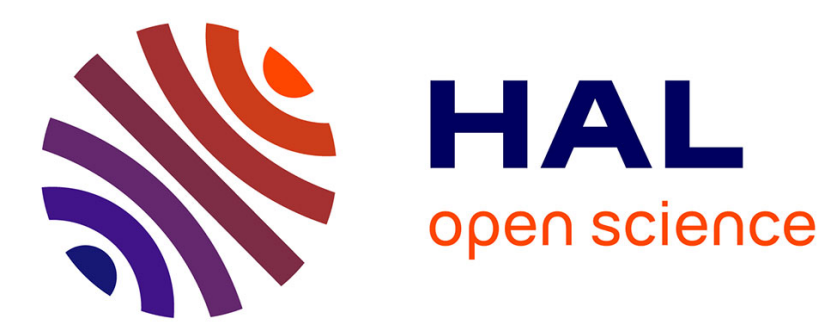

\title{
An integrated on-chip sirtuin assay
}

Detlev Belder

\section{- To cite this version:}

Detlev Belder. An integrated on-chip sirtuin assay. Electrophoresis, 2010, 31 (17), pp.3263. 10.1002/elps.201000220 . hal-00599467

\section{HAL Id: hal-00599467 https://hal.science/hal-00599467}

Submitted on 10 Jun 2011

HAL is a multi-disciplinary open access archive for the deposit and dissemination of scientific research documents, whether they are published or not. The documents may come from teaching and research institutions in France or abroad, or from public or private research centers.
L'archive ouverte pluridisciplinaire HAL, est destinée au dépôt et à la diffusion de documents scientifiques de niveau recherche, publiés ou non, émanant des établissements d'enseignement et de recherche français ou étrangers, des laboratoires publics ou privés. 


\section{ELECTROPHORESIS}

\section{An integrated on-chip sirtuin assay}

\begin{tabular}{|c|c|}
\hline Journal: & Electrophoresis \\
\hline Manuscript ID: & elps.201000220.R1 \\
\hline Wiley - Manuscript type: & Short Communication \\
\hline $\begin{array}{r}\text { Date Submitted by the } \\
\text { Author: }\end{array}$ & 26-May-2010 \\
\hline Complete List of Authors: & Belder, Detlev; Universität Leipzig, Institut für Analytische Chemie \\
\hline Keywords: & sirtuin, lab-on-a-chip, electrophoresis, reaction \\
\hline
\end{tabular}

\section{今 scholaroNE" \\ Manuscript Central}


Short Communication

\section{An integrated on-chip sirtuin assay}

\section{Stefan Ohla ${ }^{1}$, Reinhild Beyreiss ${ }^{1}$, Gerhard K. E. Scriba ${ }^{2}$, Yi Fan ${ }^{2}$ and Detlev Belder $^{1}$}

1 University of Leipzig, Institute of Analytical Chemistry, Johannisallee 29, 04103 Leipzig, Germany

2 University of Jena, Department of Pharmaceutical Chemistry, Philosophenweg 14, 07743 Jena, Germany

Keywords: high-throughput screening, inhibitor screening, lab-on-a-chip, microchip, sirtuin

Total number of words including Figure and table legends:

Correspondence: Prof. Dr. Detlev Belder, Institute of Analytical Chemistry, University of Leipzig, Linnéstr. 3, D-04103 Leipzig, Germany

E-mail: belder@uni-leipzig.de

Fax: $+49-341-9736115$

Abbreviations: HPMC, hydroxypropylmethylcellulose; Sir, silent information regulator; SIRT, sirtuins 
A microchip-based assay to monitor the conversion of peptide substrates by human recombinant sirtuin 1 (hSIRT1) is presented. For this purpose a fused-silica microchip consisting of a microfluidic separation structure with an integrated serpentine micromixer has been used. As substrate for the assay we used a 9-fluorenylmethoxycarbonyl (Fmoc)-labeled tetrapeptide derived from the amino acid sequence of p53, a known substrate of hSIRT1. The Fmoc group at the $\mathrm{N}$-terminus resulting from solid phase peptide synthesis enabled deep UV laserinduced fluorescence detection with excitation at $266 \mathrm{~nm}$. The enzymatic reaction of $0.1 \mathrm{U} / \mu \mathrm{L}$ hSIRT1 was carried out within the serpentine micromixer using a $400 \mu \mathrm{M}$ solution of the peptide in buffer. In order to reduce protein adsorption, the reaction channel was dynamically coated with hydroxypropylmethyl cellulose (HPMC). The substrate and the deacetylated product were separated by microchip electrophoresis on the same chip. The approach was successfully utilized to screen various sirtuin inhibitors. 
Sirtuins, also called class III histone deacetylases, represent a family of nicotinamide adenine dinucleotide $\left(\mathrm{NAD}^{+}\right)$-dependent enzymes that catalyze the deacetylation of acetyllysine residues of histones, transcription factors and other proteins. The catalytic mechanism includes a transfer of the acetyl group to the cofactor $\mathrm{NAD}^{+}$yielding nicotinamide, 2'-O-acetyl-ADP-ribose and deacetylated protein as products [1,2,3]. At least seven members of this protein family have been identified in humans (hSIRT1hSIRT7) [4], which differ in their cellular location and their respective substrates. Class III deacetylases have been associated with cellular functions that are involved in age-related diseases, e.g. obesity, type-II diabetes and neurodegenerative disorders like Alzheimer's and Parkinson's disease [2]. However, the whole complexity of biological pathways and mechanisms is not completely understood up to now. Therefore, it is important to develop powerful screening methods to investigate activities, substrate specifities or the effectiveness of potential activators and inhibitors.

In the literature several assays for sirtuin enzymes have been reported. Early approaches monitored the release of radioactive products derived from either ${ }^{3}[\mathrm{H}]$-acetylated substrates $[1,5,6,7]$ or ${ }^{14}[\mathrm{C}]-\mathrm{NAD}^{+}$and ${ }^{32}[\mathrm{P}]-\mathrm{NAD}^{+}$, respectively $[8,9]$. Later developments mainly utilized fluorescence detection, e.g. the commercially available Fluor de $L_{y s}{ }^{T M}$ assay. It is based on the deacetylation of acetylated tetrapeptides labeled with 7-amino-4methylcoumarin at the C-terminus. After enzymatic conversion the product becomes a substrate for trypsin, generating an increase in fluorescence by the release of the fluorophore $[10,11,12]$. An alternative method using Z-Mal as a substrate was shown by Heltweg et al. $[13,14]$. Other approaches include the separation of acetylated peptides and their respective deacetylated products by high performance liquid chromatography (HPLC) after enzymatic reaction [1,9,15]. Furthermore, Marcotte et al. reported on a fluorescence resonance energy transfer (FRET)-based assay using peptides modified with a quencher 
at the N-terminus and a fluorophore at the C-terminus [16]. Liu and coworkers used Caliper's sipper chips to realize a microfluidic mobility shift assay for the determination of $\mathrm{K}_{\mathrm{m}}$ and $\mathrm{IC}_{50}$ values [17]. They also employed luciferase in a bioluminescence assay [17] based upon quantitation of remaining $\mathrm{NAD}^{+}$. Moreover, the deacetylation of proteins has been studied by means of an enzyme-linked immunosorbent assay (ELISA) [18]. Scriba's group demonstrated the determination of kinetic and inhibition parameters of hSIRT1 and hSIRT2 establishing a validated capillary electrophoresis (CE) method. As substrates 9-fluorenylmethoxycarbonyl (Fmoc)-labeled peptides were synthesized and evaluated $[19,20]$. Recently, Denu's group developed a spectroscopic assay capable of determining steady-state kinetic parameters and continuous product monitoring. Formed nicotinamide is converted on a microplate by additional enzymatic and oxidative steps yielding $N A D(P)^{+}$ [21]. Finally, a fluorogenic assay based on the quantification of remaining $\mathrm{NAD}^{+}$was published. In this approach the remaining cofactor is converted to a highly fluorescent compound with a two-step fluorogenic reaction [22].

Although various analytical approaches are already described in the literature, there is a need for very fast methods. In this context chip-based microfluidic techniques integrating chemical reactions and analysis on a single device are very attractive $[23,24]$. An ideal technique for high speed on-chip separations is chip electrophoresis enabling separations within seconds or even subseconds [25, 26, 27] applying very high field strengths. In previous work we demonstrated a first approach for integrating chemical reactions and analysis on a single microchip for the screening of enantioselective biocatalysts [28].

In the current work we extended this approach to develop a rapid microfluidic assay to investigate the deacetylation of acetyl-lysine residues by sirtuin enzymes. The technique was evaluated for the identification of potential inhibitors.

The peptidic structure of the substrate derives from the amino acid sequence of the transcription factor p53 which is a known substrate for the enzyme hSIRT1. The positions 
379-382 of this protein are $\mathrm{RHKK}(\mathrm{Ac})$, where acetylation and deacetylation appear at lysine 382 [29]. In order to monitor the hSIRT1-catalyzed conversion of acetylated lysine residues a tetrapeptide based on this amino acid sequence and the respective deacetylated peptide have been synthesized as described elsewhere [19]. After synthesis the Fmoc group was not cleaved from the $\mathrm{N}$-terminus providing a fluorophore suitable for deep UV laser excitation at $266 \mathrm{~nm}$ for both peptides, the substrate Fmoc-RHKK(Ac)-NH and the product Fmoc- $\mathrm{RHKK}-\mathrm{NH}_{2}$. The experimental determination of fluorescence properties $(\lambda($ exc. $)=266 \mathrm{~nm})$ of all compounds involved in the reaction was carried out (data not shown). For the peptide substrate and its deacetylated analog a significant fluorescence emission with $\lambda_{\max }(\mathrm{em})=.310 \mathrm{~nm}$ was observed due to the fluorophoric group Fmoc. In contrast, no fluorescence signal was detected for the cofactor $\mathrm{NAD}^{+}$and for nicotinamide.

For on-chip experiments a system based on a commercially available inverted fluorescence microscope IX-71 (Olympus, Hamburg, Germany) has been used that was upgraded to allow laser-induced fluorescence detection with excitation at $266 \mathrm{~nm}$ as described earlier [30]. The chip design as well as the working principle of the fused-silica microchip (Micronit, Enschede, Netherlands) is illustrated in Figure 1. The microfluidic structure was manufactured by common isotropic etching with hydrofluoric acid. It mainly consists of two functional parts. A simple cross injector including a $70 \mathrm{~mm}$ long separation channel is used for the electrophoretic separation of reaction products. A long meandering channel linked to the separation part serves as microfluidic reactor where enzymatic conversions are performed. At the end of each channel access holes are implemented to access the microfluidic structure. These microvials are labeled sample outlet (SO), alternative sample inlet $(\mathrm{SI})$, buffer inlet $(\mathrm{BI})$, buffer outlet $(\mathrm{BO})$ and sample inlets (A and B). 
Figure 1. Schematic drawing of the microchip illustrating the working principle. SO: sample outlet, SI: alternative sample inlet, BI: buffer inlet, BO: buffer outlet, A and B: sample inlets.

To prepare the microchip for electrophoretic measurements all channels were initially rinsed with $0.1 \mathrm{M} \mathrm{NaOH}$ and deionized water for 4 min. Afterwards, the surface of all microchannels was coated dynamically with HPMC in order to improve the performance and reproducibility of the electrophoretic separation. Therefore, the microfluidic structure was filled with a solution containing $0.025 \% \mathrm{HPMC}(\mathrm{m} / \mathrm{v})$ in water for $5 \mathrm{~min}$.

The electrophoretic separation of a standard mixture of both peptides containing $200 \mu \mathrm{M}$ of each analyte was optimized, especially by evaluating different separation buffers. Baseline separation was achieved utilizing a $200 \mathrm{mM}$ Tris-phosphate buffer at pH 2.7 After optimization of the voltage program for a pinched injection the electropherogram shown in Figure 2 was obtained using the electrical potentials given in the caption. 


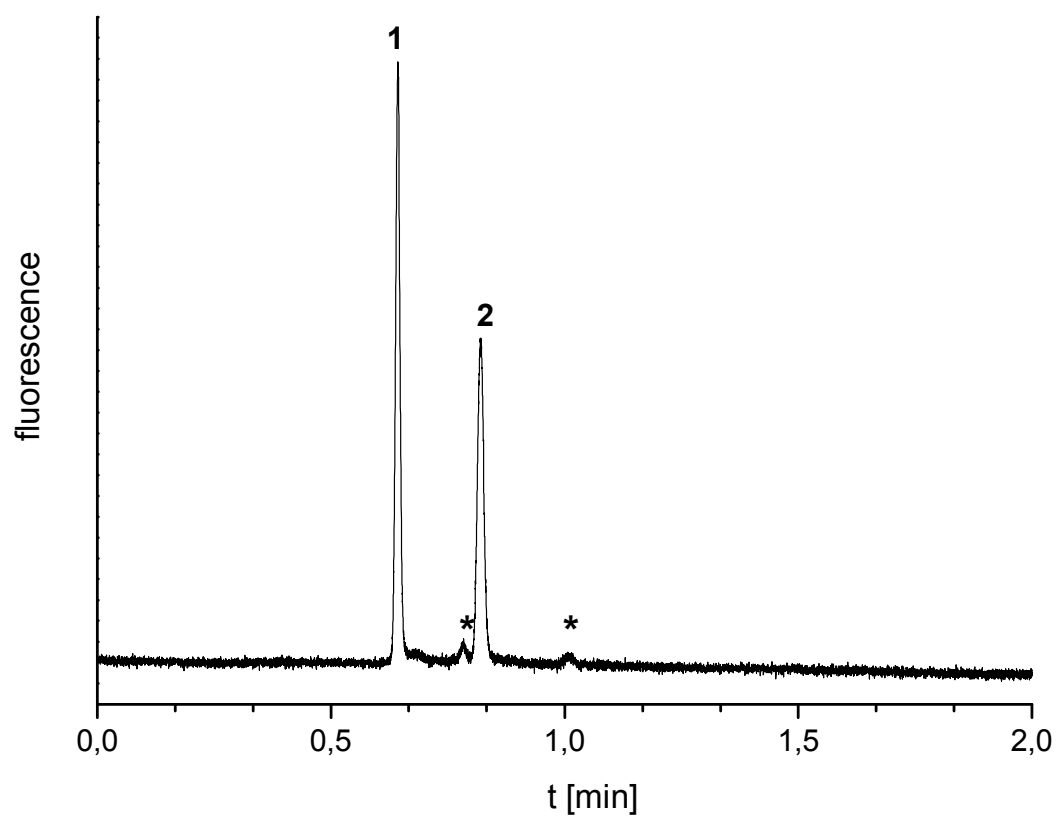

Figure 2. Electropherogram of a mixture of the estimated product $\mathrm{Fmoc}-\mathrm{RHKK}-\mathrm{NH}_{2}$ (1) and the acetylated substrate Fmoc-RHKK(Ac)- $\mathrm{NH}_{2}(2)$ obtained at a concentration of $200 \mu \mathrm{M}$ each. $\left(^{*}\right)$ impurities due to solid phase peptide synthesis. Buffer, $200 \mathrm{mM}$ Tris-phosphate, $\mathrm{pH} 2.7$. Effective separation length $2.7 \mathrm{~cm}$. Injection potentials, $\mathrm{BI}-0.4$ BO 0.8 A/B 4.0 SO -0.8 (kV). Separation potentials, BI 2.4 BO 0.0 A/B 1.4 SO $2.0(\mathrm{kV})$. Channel surface dynamically coated with HPMC.

The detection point was set to a separation length of $2.7 \mathrm{~cm}$ allowing baseline-separation of both compounds $\left(R_{S}=7.9\right)$ in less than one minute. In order to investigate the reproducibility of the system repetitive separations $(n=4)$ were performed and the peak area ratios of the signal of the starting material to that of the product were calculated. In these experiments we obtained quite acceptable relative standard deviation of $2 \%$ at peak area ratios of about 0.78 . Peak assignment was realized by common standard addition. The signal marked with $1\left(t_{m}=0.64 \mathrm{~min}, \mathrm{~N}=18930\right)$ corresponds to $\mathrm{Fmoc}-\mathrm{RHKK}-\mathrm{NH}_{2}$ which has a shorter migration time due to the additional charge and thus higher electrophoretic mobility. Signal $2\left(t_{m}=0.82 \mathrm{~min}, \mathrm{~N}=15831\right)$ can be attributed to Fmoc- 
$\mathrm{RHKK}(\mathrm{Ac})-\mathrm{NH}_{2}$. In all experiments the signal for the respective peptide was accompanied by a small impurity at longer migration times. These signals are marked with * in Figure 2. We assume these impurities derive from solid phase peptide synthesis where the purity of all peptides was greater than $97 \%$ as determined by analytical HPLC [19].

Based on these results the separation procedure was combined with the on-chip reaction i.e. the formation of deacetylated product within the meandering reaction structure. For the enzymatic reaction it is important to minimize any activity loss of the rather delicate enzyme hSIRT1. In order to ensure physiological working conditions the reaction solutions were incubated at a temperature of $37^{\circ} \mathrm{C}(20 \mathrm{~min})$ before introduction into the chip. In initial experiments we observed a decrease of enzyme activity using bare fused silica chips, which was attributed to protein surface interactions. The problem of enzyme deactivation by adsorption is also apparent in traditional macroscopic methods, where BSA is often added to the reaction medium at rather high concentrations to prevent enzyme adsorption to the surface of the reaction vessel. However, this approach is hardly adaptable for microchip electrophoresis as the addition of BSA at high concentrations leads to plugged microchannels resulting in non-reproducible results. We therefore evaluated the common dynamic surface modification procedure applied in chip electrophoresis [31] by simply rinsing the channels with a solution of a hydrophilic surface active polymers like hydroxypropylmethylcellulose (HPMC). Applying such a dynamic HPMC-coating before each experiment improved the reproducibility of the reaction and the activity of the enzyme significantly. A considerably higher signal of deacetylated peptide was obtained in comparison to the results using a bare channel surface. For on-chip experiments a substrate solution with $400 \mu \mathrm{M}$ Fmoc-RHKK(Ac)- $\mathrm{NH}_{2}$ and $2 \mathrm{mM} \mathrm{NAD}^{+}$was employed. Furthermore, the enzyme solution had a concentration of $0.1 \mathrm{U} / \mu \mathrm{L}$ hSIRT1. Both solutions were prepared in Tris buffer $(50 \mathrm{mM}, \mathrm{pH} 8.0)$, containing $137 \mathrm{mM} \mathrm{NaCl}$, $2.7 \mathrm{mM} \mathrm{KCl}$ and $1 \mathrm{mM} \mathrm{MgCl}_{2}$. After pipetting the reactant solutions in the respective 
microvial A or B (Figure 1), vacuum was applied at SI in order to merge the liquids through the meandering reaction channel. Afterwards the other channels and microvials were filled with separation buffer (200 mM Tris-phosphate buffer, $\mathrm{pH}$ 2.7). The reaction products were then transported to the separation channel by applying voltage at the access holes $A, B$, $\mathrm{BI}, \mathrm{BO}$ and SO. After $90 \mathrm{~s}$ of this pinched injection program [32] the potentials were switched to separation mode. The fraction of the reaction mixture in the cross section was injected into the separation channel followed by subsequent separation in the electric field. In contrast to most assays described in literature the reaction was not stopped by the addition of TFA [16] or equivalent substances. Specific reaction times were determined by switching the voltage program to separation mode and thus initiating the injection of a sample plug. With the current not optimized setup with rather long reaction channels the minimum reaction time monitored was about $10 \mathrm{~min}$.

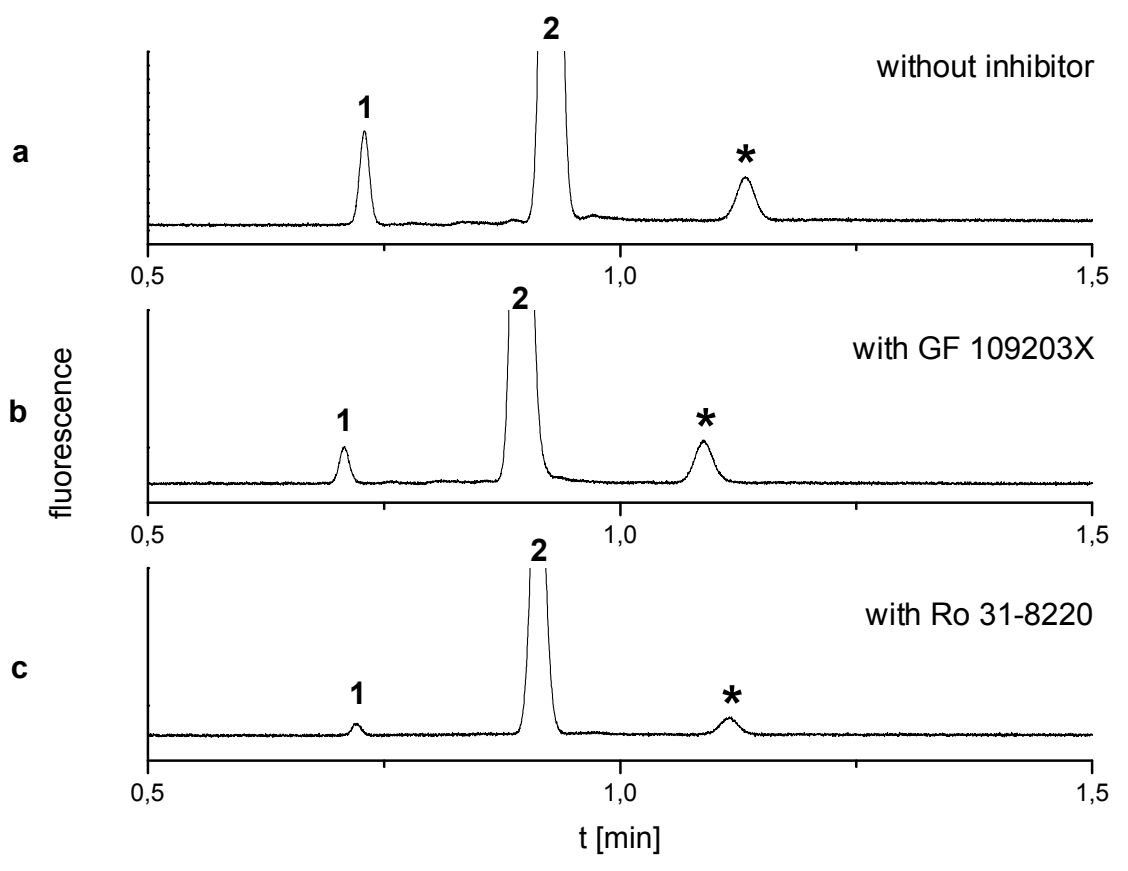

Figure 3. Electropherograms obtained after on-chip deacetylation in the presence of two different inhibitors compared to the result of a reaction without inhibitor: Fmoc-RHKK-NH 2 (1), Fmoc-RHKK(Ac)- $\mathrm{NH}_{2}(2),\left(^{*}\right)$ impurities due to solid phase peptide 
synthesis. Conditions are as described in the caption of Figure 2. Zoom factors of all electropherograms are identical.

An electropherogram obtained after on-chip enzymatic conversion with subsequent electrophoretic separation using coated microchannels is shown in Figure 3a. Retention times were $0.73 \min (\mathrm{N}=20464)$ for $F$ moc-RHKK-NH$H_{2}$ and $0.93 \min (\mathrm{N}=14164)$ for Fmoc-RHKK(Ac)-NH $\mathrm{NH}_{2}$ and thus analogous to the results displayed in Figure 2. The interday variations in migration times comparing figure 3 and figure 2 can be explained by variations in temperature and also by a slight variation in the manual alignment of the channel in the ray path of the homebuilt system.

The setup allowed to monitor the activity of the enzyme quite well. Moreover, we evaluated the applicability of the system to the screening of inhibitors. For these proof of principle experiments three known inhibitors for sirtuin enzymes were chosen, namely GF 109203X [33], Ro 31-8220 [33] and sirtinol [34]. Inhibition studies were carried out by adding $200 \mu \mathrm{M}$ of the respective inhibitor to the substrate solution. To guarantee comparable results onchip experiments were performed using similar reaction times. Electropherograms obtained after on-chip deacetylation in presence of GF 109203X and Ro 31-8220 are shown in Figure $3 b$ and Figure $3 c$. Resulting migration times and plate numbers were consistent with the data acquired for reactions without inhibitor. After calculating the peak area (starting material) to peak area (product) ratio values of 17.8 (without inhibitor), 37.1 (with GF 109203X) and 43.1 (with Ro 31-8220) were obtained. Taking into account that the standard deviation is about $2 \%$ as shown above the decrease of the product signal in the presence of an inhibitor can be regarded as significant. Additionally it can be stated that Ro $31-8220$ is a more effective inhibitor for hSIRT1 than GF 109203X which is in agreement with the literature [20,33]. When the on-chip reaction was performed in presence of sirtinol no inhibition was observed. In the literature controversial reports on the 
[1] Tanner, K. G., Landry, J., Sternglanz, R., Denu, J. M., Proc. Natl. Acad. Sci. USA 2000, 97, 14178-14182.

[2] Haigis, M. C., Guarente, L. P., Gene Dev. 2006, 20, 2913-2921.

[3] Michan, S., Sinclair, D., Biochem. J. 2007, 404, 1-13.

[4] Frye, R. A., Biochem. Biophys. Res. Commun. 2000, 273, 793-798.

[5] Bedalov, A., Gatbonton, T., Irvine, W. P., Gottschling, D. E., Simon, J. A., Proc. Natl. Acad. Sci. USA 2001, 98 , $15113-15118$.

[6] Jackson, M. D., Denu, J. M., J.Biol. Chem. 2002, 277, 18535-18544.

[7] Kaeberlein, M., McDonagh, T., Heltweg, B., Hixon, J., et al., J. Biol. Chem. 2005, 280, 17038-17045.

[8] Borra, M. T., Langer, M. R., Slama, J. T., Denu, J. M., Biochemistry 2004, 43, 9877-9887.

[9] Borra, M. T., Denu, J. M., Methods Enzymol. 2004, 376, 171-187.

[10] Howitz, K. T., Bitterman, K. J., Cohen, H. Y., Lamming, D. W., et al., Nature 2003, 425, 191-196.

[11] Borra, M. T., Smith, B. C., Denu, J. M., J. Biol. Chem. 2005, 280, 17187-17195. 
[12] Mai, A., Massa, S., Lavu, S., Pezzi, R., et al., J. Med. Chem. 2005, 48, 7789-7795.

[13] Heltweg, B., Trapp, J., Jung, M., Methods 2005, 36, 332-337.

[14] Heltweg, B., Dequiedt, F., Verdin, E., Jung, M., Anal. Biochem. 2003, 319, 42-48.

[15] deBoer, V. C. J., deGoffau, M. C., Arts, I. C. W., Hollman, P. C. H., Keijer, J., Mech. Aging Dev. 2006, 127, 618627.

[16] Marcotte, P. A., Richardson, P. R., Guo, J., Barrett, L. W., et al., Anal. Biochem. 2004, 332, 90-99.

[17] Liu, Y., Gerber, R., Wu, J., Tsuruda, T., McCarter, J. D., Anal. Biochem. 2008, 378, 53-59.

[18] Schlicker, C., Gertz, M., Papatheodorou, P., Kachholz, B., Becker, C. F. W., Steegborn, C., J. Mol. Biol. 2008, 382, 790-801.

[19] Fan, Y., Ludewig, R., Imhof, D., Scriba, G. K. E., Electrophoresis 2008, 29, 3717-3723.

[20] Fan, Y., Ludewig, R., Scriba, G. K. E., Anal. Biochem. 2009, 387, 243-248.

[21] Smith, B. C., Hallows, W. C., Denu, J. M., Anal. Biochem. 2009, 394, 101-109.

[22] Feng, Y., Wu, J., Chen, L., Luo, C., Shen, X., Chen, K., Jiang, H., Liu, D., Anal. Biochem. 2009, 395, $205-210$.

[23] Janasek, D., Franzke, J., Manz, A., Nature 2006, 442, 374-380.

[24 ] Belder, D., Angew. Chem. Int. Ed. 2009, 48, 3736 - 3737

[25] Piehl, N.,Ludwig, M., Belder, D., Electrophoresis 2004, 25, 3848-3852.

[26] Jacobson, S. C., Culbertson, C. T.,Daler, J. E., Ramsey, J. M., Anal. Chem. 1998, 70, 3476-3480.

[27] Fritzsche, S., Hoffmann, P., Belder, D., Lab Chip 2010, 10, 1227-1230.

[28] Belder, D., Ludwig, M., Wang, L.-W., Reetz, M. T., Angew. Chem. Int. Ed. 2006, 45, 2463-2466.

[29] Vaziri, H., Dessain, S. K., Ng Eaton, E., Imai, S. I., et al., Cell 2001, 107, 149-159.

[30] Schulze, P., Ludwig, M., Kohler, F., Belder, D., Anal. Chem. 2005, 77, 1325-1329.

[31] Belder, D., Ludwig, M., Electrophoresis, 2003, 24, 3595-3606.

[32] Jacobson, S. C., Hergenroder, R., Koutny, L. B., Warmack, R. J., Ramsey, J. M., Anal. Chem. 1994, 66, 11071113 .

[33] Trapp, J., Jochum, A., Meier, R., Saunders, L., Marshall, B., Kunick, C., Verdin, E., Goekjian, P., Sippl, W., Jung, M., J. Med. Chem. 2006, 49, 7307-7316.

[34] Grozinger, C. M., Chao, E. D., Blackwell, H. E., Moazed, D., Schreiber, S. L., J. Biol. Chem. 2001, 276, 3883738843 .

[35] Sauve, A. A., Wolberger, C., Schramm, V. L., Boeke, J. D., Annu. Rev. Biochem. 2006, 75, 435-465. 